\title{
Toxoplasmosis in heart and heart and lung transplant recipients
}

\author{
T G WREGHITT, * M HAKIM ${ }^{*}$ J J GRAY,* A H BALFOUR, $\dagger$ P G I STOVIN, $\ddagger$ \\ SUSAN STEWART, $\ddagger$ J SCOTT,§ T A H ENGLISH, $\|$ J WALLWORK\| \\ *Clinical Microbiology and Public Health Laboratory, Addenbrooke's Hospital, Cambridge, the †Toxoplasma \\ Unit, Public Health Laboratory, Leeds, the $\ddagger$ Sims Woodhead Memorial Laboratory, the §Department of \\ Respiratory Medicine, and the $\|$ Cardiothoracic Surgery Unit, Papworth Hospital, Cambridge
}

SUMmary Of the first 250 heart and 35 heart and lung transplant recipients at Papworth Hospital, Cambridge, who survived for more than one month after transplantation, 217 heart and 33 heart and lung patients were investigated serologically for evidence of Toxoplasma gondii infection. Six patients acquired primary $T$ gondii infection, most probably from the donor organ. Five patients experienced $T$ gondii recrudescence, two of whom had recovered from primary infection a few years earlier. Two patients died from primary $T$ gondii infection and the severity of symptoms in the other patients with primary infection was related to the amount of immunosuppressive treatment. Prophylaxis with pyrimethamine ( $25 \mathrm{mg}$ a day for six weeks) was introduced for $T$ gondii antibody negative transplant recipients who received a heart from a $T$ gondii antibody positive donor after the first four cases of primary toxoplasmosis. Of the seven patients not given pyrimethamine, four $(57 \%)$ acquired primary $T$ gondii infection. This compared with two of the 14 patients (14\%) given prophylaxis.

Toxoplasma gondii is a ubiquitous pathogen. In the United Kingdom about $30 \%$ of persons aged 40 years have serological evidence of previous infection.' $T$ gondii infections are usually asymptomatic, but infection may present as a glandular fever-like illness which is usually self-limiting with full recovery. In contrast, primary $T$ gondii infections in immunocompromised persons are generally symptomatic, often presenting as necrotising encephalitis, myocarditis, or pneumonitis. ${ }^{2}$ There have been many reports of clinical toxoplasmosis in patients with neoplastic disease ${ }^{3}$ with the acquired immune deficiency syndrome (AIDS), ${ }^{4}$ as well as in immunosuppressed recipients of kidney, ${ }^{25}$ liver, ${ }^{26}$ heart ${ }^{78}$ and bone marrow transplants. ${ }^{9}$ Some of these infections seem to have been acquired from the donated organ ${ }^{578}$ and some follow reactivation of latent $T$ gondii cysts, ${ }^{79}$ which may lie dormant but potentially active for many years. ${ }^{1011}$ In some reports, however, the serological findings are insufficient to permit differentiation between primary and reactivated infections.

Having prospectively studied $T$ gondii serological responses in 217 heart and 33 heart and lung trans-

Accepted for publication 14 September 1988 plant recipients at Papworth Hospital, Cambridge, we now provide a detailed account of serological and clinical responses to $T$ gondii primary and recrudescent infection in these patients.

\section{Material and methods}

A total of 250 patients received heart and 35 received heart and lung transplants between January 1979 and January 1988. The first 29 of these patients received conventional immunsuppression with azathioprine and prednisolone as well as a prophylactic course of intravenous equine anti-thymocyte globulin (ATG) for 28 days. ${ }^{12}$ The next 60 patients received cyclosporin $\mathrm{A}$ and low doses of steroids, ${ }^{13}$ while the following 60 patients received either this regimen or cyclosporin $A$ and azathioprine. Thereafter, patients received triple treatment with cyclosporin A, prednisolone, and azathioprine. The initial maintenance doses of these three agents were: cyclosporin A 8-10 mg/kg/day so as to maintain whole blood "trough" values at $800-1200$ $\mathrm{ng} / \mathrm{kg} /$ day; azathioprine $1-2 \mathrm{mg} / \mathrm{kg} /$ day, to obtain a white cell count of 5-6 $\times 10^{9} / 1$; heart transplant patients received prednisolone $1 \mathrm{mg} / \mathrm{kg} /$ day reducing - to a maintenance dose of $0.25 \mathrm{mg} / \mathrm{kg} /$ day after two weeks; while heart and lung transplant patients 
received prednisolone $375 \mathrm{mg} /$ day for one day. All patients treated with cyclosporin A received a three day course of ATG in the period immediately following surgery.

Serum samples were obtained from patients before transplantation and at weekly intervals during the patient's stay in hospital, and thereafter, when they attended as outpatients or were readmitted to hospital. Serum samples were also received from organ donors. Since June $1984 T$ gondii antibody negative recipients who received an organ from a $T$ gondii antibody positive donor-that is, mismatched for $T$ gondiiwere given a six week prophylactic course of pyrimethamine $(25 \mathrm{mg} /$ day $)$ and folinic acid (15 $\mathrm{mg}$ three times a day).

\section{T GONDII LATEX AGGLUTINATION TEST}

The latex agglutination test (Toxoreagent, Eiken Chemical Company of Japan, supplied by MAST Diagnostics Ltd, Bootle, Merseyside, England) was performed as recommended by the manufacturers on all serum samples. Antibody titres of $\geqslant 16$ were considered to be positive.

\section{T GONDII DYE TEST}

The dye test was performed in flat-bottomed, microtitre plates and read directly by means of an inverted microscope, as previously described. ${ }^{14}$

\section{HAEMAGGLUTINATION TEST}

The indirect haemagglutination test was performed in microtitre plates with V-shaped wells and with sensitised turkey erythrocytes, as previously described. ${ }^{15}$

\section{$\mu$-CAPTURE ELISA FOR DETECTING T GONDII-} SPECIFIC IGM

The antibody class capture (ACC) enzyme-linked immunosorbent assay (ELISA) for detecting $T$ gondiispecific IgM, previously described by Payne et al,${ }^{16}$ was used. Results were expressed in enzyme immunoassay units (EIU). A positive control serum was used as a reference standard.

\section{CARDIAC MUSCLE BIOPSY SPECIMENS}

Cardiac muscle biopsy specimens were obtained at various times after transplantation, as specified for each patient. They were processed and examined, as described by Pomerance and Stovin. ${ }^{17}$ As a result of the small size of the cysts in relation to the standard section thickness of 5-7 $\mu \mathrm{m}$ it was necessary to examine serial sections to increase the chance of finding cysts. The presence of myocyte necrosis without an accompanying cellular infiltrate or the presence of fibrotic replacement of individual myocytes alerts the histopathologist to the possibility of Toxoplasma myocarditis. ${ }^{18}$
TRANSBRONCHIAL BIOPSY SPECIMENS

Transbronchial biopsy specimens were taken as described by Higenbottom et $a^{6}$ for investigating new and changed pulmonary symptoms in heart and lung transplant recipients.

\section{Results}

Two hundred and seventeen heart transplant and 33 heart and lung transplant patients survived for at least one month after transplantation from whom regular serum samples and the respective donor's serum were available. The numbers of donors and recipients who were $T$ gondii antibody positive at the time of transplantation and the numbers of $T$ gondii mismatched patients (antibody negative recipient, antibody positive donor) are shown in table 1 .

Patients who had no detectable $T$ gondii antibody before transplantation and who subsequently developed $T$ gondii antibody titres were regarded as having primary infections. Six patients in this series acquired primary $T$ gondii infection, probably from the donor's heart. A summary of the antibody responses to infection in these patients is shown in table 2.

Patients who had detectable $T$ gondii antibody and subsequently had a rise in $T$ gondii antibody titres were regarded as having recrudescence of $T$ gondii. Five patients showed evidence of $T$ gondii recrudescence at some time after transplantation. Two patients (cases 3 and 4) had previously acquired primary $T$ gondii infection. A summary of the antibody responses to $T$ gondii recrudescence for the three remaining patients is shown in table 3. A detailed case history for each patient is as follows.

\section{CASE HISTORIES}

A 32 year old man (case 1) had received a heart

Table 1 Summary of $T$ gondii antibody state of donors and recipients

\begin{tabular}{llll}
\hline & \multicolumn{3}{l}{ Transplant patients (\%) } \\
\cline { 2 - 4 } & $\begin{array}{l}\text { Heart } \\
(n=250)\end{array}$ & $\begin{array}{l}\text { Heart and lung } \\
(n=35)\end{array}$ & $\begin{array}{l}\text { Total } \\
(n=285)\end{array}$ \\
\hline $\begin{array}{c}\text { Total studied } \\
\text { No of } T \text { gondii } \\
\text { antibody positive } \\
\text { donors }\end{array}$ & 217 & 33 & $250(87 \cdot 7)$ \\
$\begin{array}{c}\text { No of } T \text { gondii } \\
\text { antibody positive } \\
\text { recipients }\end{array}$ & $49(22 \cdot 6)$ & $3(9 \cdot 1)$ & $52(20 \cdot 8)$ \\
$\begin{array}{c}\text { No of patients } \\
\text { mismatched for } \\
T \text { gondii }\end{array}$ & $64(29 \cdot 5)$ & $11(33 \cdot 3)$ & $75(30)$ \\
\hline
\end{tabular}

*The first seven patients were not given prophylaxis with pyrimethamine; the next 13 patients were.

this patient was given prophylaxis with pyrimethamine. $\ddagger T$ gondii antibody negative recipient, antibody positive organ donor. 
Table 2 Antibody titres in heart transplant patients with $T$ gondii infections

\begin{tabular}{|c|c|c|c|c|c|c|}
\hline \multirow[b]{2}{*}{ Case No } & \multirow{2}{*}{$\begin{array}{l}\text { Time after } \\
\text { transplant }\end{array}$} & \multirow{2}{*}{$\begin{array}{l}\text { Latex } \\
\text { agglutination } \\
\text { test titre }\end{array}$} & \multicolumn{2}{|c|}{ Dye test } & \multirow[b]{2}{*}{$\begin{array}{l}\text { Haemagglutination } \\
\text { test titre }\end{array}$} & \multirow[b]{2}{*}{$\begin{array}{l}T \text { gondii } \\
\text { specific } \operatorname{Ig} M(E I U)\end{array}$} \\
\hline & & & Titre & $I U$ & & \\
\hline 1 & $\begin{array}{l}\text { Before } \\
\text { Donor } \\
27 \mathrm{~d} \\
33 \mathrm{~d} \\
44 \mathrm{~d}\end{array}$ & $\begin{array}{l}<16 \\
512 \\
<16 \\
512 \\
\text { Died-dissemi }\end{array}$ & $\begin{array}{l}<8 \\
256 \\
<8 \\
64 \\
\text { ed } T \text { gon }\end{array}$ & $\begin{array}{l}<2 \\
62 \\
<2 \\
15 \\
\text { necropsy }\end{array}$ & $\begin{array}{l}<32 \\
512 \\
<32 \\
32\end{array}$ & $\begin{array}{r}0 \\
0 \\
0 \\
101\end{array}$ \\
\hline 2 & $\begin{array}{l}\text { Before } \\
\text { Donor } \\
29 \mathrm{~d} \\
33 \mathrm{~d} \\
34 \mathrm{~d}\end{array}$ & $\begin{array}{l}<16 \\
256 \\
<16 \\
<16 \\
\text { Died-T gond }\end{array}$ & $\begin{array}{l}<8 \\
128 \\
<8 \\
<8 \\
\text { en in hea }\end{array}$ & $\begin{array}{l}<2 \\
31 \\
<2 \\
<2\end{array}$ & $\begin{array}{l}<32 \\
1024 \\
<32 \\
<32\end{array}$ & $\begin{array}{l}0 \\
0 \\
0 \\
7\end{array}$ \\
\hline 3 & $\begin{array}{l}\text { Before } \\
\text { Donor } \\
22 \mathrm{~d} \\
33 \mathrm{~d} \\
1 \mathrm{y} \\
2 \mathrm{y} \\
4 \cdot 5 \mathrm{y}\end{array}$ & $\begin{array}{l}<16 \\
32 \\
<16 \\
128 \\
<16 \\
256 \\
4096\end{array}$ & $\begin{array}{l}<8 \\
64 \\
<8 \\
2048 \\
128 \\
128 \\
512\end{array}$ & $\begin{array}{l}<2 \\
15 \\
<2 \\
500 \\
31 \\
31 \\
125\end{array}$ & $\begin{array}{l}<32 \\
128 \\
<32 \\
256 \\
32 \\
32 \\
512\end{array}$ & $\begin{array}{r}0 \\
0 \\
2 \\
85 \\
4 \\
0 \\
0\end{array}$ \\
\hline 4 & $\begin{array}{l}\text { Before } \\
\text { Donor } \\
18 \mathrm{~d} \\
28 \mathrm{~d} \\
1 \mathrm{y} \\
2 \mathrm{y}\end{array}$ & $\begin{array}{l}<16 \\
N T \\
<16 \\
512 \\
16 \\
1024\end{array}$ & $\begin{array}{l}<8 \\
\text { NT } \\
<8 \\
2048 \\
128 \\
4096\end{array}$ & $\begin{array}{l}<2 \\
20 \\
<2 \\
500 \\
31 \\
1000\end{array}$ & $\begin{array}{l}<32 \\
\mathrm{NT} \\
<32 \\
128 \\
<32 \\
64\end{array}$ & $\begin{array}{r}0 \\
\text { NT } \\
0 \\
216 \\
43 \\
96\end{array}$ \\
\hline 5 & $\begin{array}{l}\text { Before } \\
\text { Donor } \\
6 \mathrm{~m} \\
14 \mathrm{~m}\end{array}$ & $\begin{array}{l}<16 \\
64 \\
<16 \\
1024\end{array}$ & $\begin{array}{l}<8 \\
64 \\
<8 \\
4096\end{array}$ & $\begin{array}{l}<2 \\
15 \\
<2 \\
1000\end{array}$ & $\begin{array}{l}<32 \\
128 \\
<32 \\
512\end{array}$ & $\begin{array}{r}0 \\
4 \\
0 \\
86\end{array}$ \\
\hline 6 & $\begin{array}{l}\text { Before } \\
\text { Donor } \\
87 \mathrm{~d} \\
115 \mathrm{~d}\end{array}$ & $\begin{array}{l}<16 \\
128 \\
<16 \\
1024\end{array}$ & $\begin{array}{l}<8 \\
64 \\
<8 \\
512\end{array}$ & $\begin{array}{l}<2 \\
15 \\
<2 \\
125\end{array}$ & $\begin{array}{l}<32 \\
256 \\
<32 \\
128\end{array}$ & $\begin{array}{r}0 \\
0 \\
0 \\
148\end{array}$ \\
\hline
\end{tabular}

transplant. He developed right-sided heart failure and right lower lobe pneumonia. In the second week poorly localised abdominal pain, persistent diarrhoea, and fever were noted but a myocardial biopsy specimen on day 12 proved normal. In the fourth week the patient had two grand mal seizures. Endomyocardial biopsy specimens taken on days 20 and 28 postoperatively showed toxoplasma cysts in the myocardium. Treatment with oral pyrimethamine $(25 \mathrm{mg} /$ day), folinic acid, and sulphadiazine $(1 \mathrm{~g}$ three times a day) was started. His condition deteriorated and he died 44 days after transplantation.

A 49 year old man (case 2) had received a heart transplant. In the third week he received enhanced immunosuppression with high doses of steroids because of a rejection episode. A myocardial biopsy specimen taken on day 24 did not show $T$ gondii cysts. From day 32 onwards he became febrile with temperatures of $38.5-39.5^{\circ} \mathrm{C}$ and rigors. He developed pneumonia and died in the morning of day 34 . Disseminated toxoplasmosis was diagnosed histologically at post mortem examination.

A 43 year old man (case 3 ) had received a heart transplant. Twenty two days after transplant he developed a persistent fever of $39 \cdot 5^{\circ} \mathrm{C}$. He was treated with oral pyrimethamine, $25 \mathrm{mg}$ twice a day, and sulphatriad, $500 \mathrm{mg}$ twice a day, when a rise in $T$ gondii antibody titres was noted. Subsequently, $T$ gondii cysts were found in cardiac biopsy specimens taken on days 36 and 58 after transplantation. Fever slowly resolved and he made a good recovery. From day 37 his dose of pyrimethamine was reduced to $25 \mathrm{mg}$ a day. He was discharged 58 days after transplantation. $T$ gondii was not found in cardiac biopsy specimens taken from day 78 onwards. A year after transplantation anti- $T$ gondii treatment was stopped. He remained generally well, although he complained of occasional headaches and slight blurring of vision. At a routine examination two years after transplantation the patient's $T$ gondii latex agglutination test titre had risen from $<16$ to 256 . A cardiac muscle biopsy specimen taken at this time showed no evidence of $T$ gondii cysts. Nevertheless, he had evidently experienced asymptomatic recrudescence of his earlier $T$ gondii infection; he remained well five years after transplantation.

A 20 year old man (case 4) had received a heart 
Table 3 Patients with $T$ gondii recrudescence

\begin{tabular}{|c|c|c|c|c|c|c|}
\hline \multirow[b]{2}{*}{ Case No } & \multirow{2}{*}{$\begin{array}{l}\text { Time after } \\
\text { transplant }\end{array}$} & \multirow{2}{*}{$\begin{array}{l}\text { Latex } \\
\text { agglutination } \\
\text { test titre }\end{array}$} & \multicolumn{2}{|c|}{ Dye test } & \multirow{2}{*}{$\begin{array}{l}\text { Haemagglutination } \\
\text { test titre }\end{array}$} & \multirow{2}{*}{$\begin{array}{l}T \text { gondii } \\
\text { specific } \operatorname{Ig} M(E I U)\end{array}$} \\
\hline & & & Titre & $I U$ & & \\
\hline 7 & $\begin{array}{l}\text { Before } \\
\text { Donor } \\
15 \mathrm{~d} \\
75 \mathrm{~d} \\
2.5 \mathrm{y}\end{array}$ & $\begin{array}{l}32 \\
<16 \\
32 \\
256 \\
64\end{array}$ & $\begin{array}{l}16 \\
<16 \\
32 \\
128 \\
128\end{array}$ & $\begin{array}{l}4 \\
<4 \\
8 \\
31 \\
31\end{array}$ & $\begin{array}{l}128 \\
<32 \\
128 \\
512 \\
128\end{array}$ & $\begin{array}{l}0 \\
0 \\
0 \\
0 \\
0\end{array}$ \\
\hline 8 & $\begin{array}{l}\text { Before } \\
\text { Donor } \\
6 \mathrm{~d} \\
12 \mathrm{~d} \\
54 \mathrm{~d} \\
2 \mathrm{y}\end{array}$ & $\begin{array}{l}<16 \\
16 \\
16 \\
64 \\
1024 \\
1024\end{array}$ & $\begin{array}{l}16 \\
32 \\
16 \\
128 \\
8194 \\
512\end{array}$ & $\begin{array}{l}4 \\
8 \\
4 \\
31 \\
2000 \\
125\end{array}$ & $\begin{array}{l}<32 \\
128 \\
32 \\
64 \\
2048 \\
1024\end{array}$ & $\begin{array}{l}0 \\
2 \\
1 \\
0 \\
3 \\
0\end{array}$ \\
\hline 9 & $\begin{array}{l}\text { Before } \\
\text { Donor } \\
53 \mathrm{~d} \\
271 \mathrm{~d} \\
406 \mathrm{~d} \\
473 \mathrm{~d}\end{array}$ & $\begin{array}{l}256 \\
16 \\
256 \\
16000 \\
256 \\
\text { Died-no evic }\end{array}$ & $\begin{array}{l}128 \\
8 \\
128 \\
16000 \\
256 \\
\text { of Toxo }\end{array}$ & $\begin{array}{l}31 \\
2 \\
31 \\
4000 \\
62 \\
\text { t necropsy }\end{array}$ & $\begin{array}{l}256 \\
32 \\
256 \\
16000 \\
512\end{array}$ & $\begin{array}{r}0 \\
0 \\
0 \\
160 \\
0\end{array}$ \\
\hline
\end{tabular}

transplant. From day 17 he developed intermittent fever and a dry cough, and culture of bronchial washings grew an Enterobacter species. Routine endomyocardial biopsy specimens taken at day 26 showed $T$ gondii cysts. Sulphadiazine, $1 \mathrm{~g}$ four times a day, and trimethoprim, $250 \mathrm{mg}$ twice a day, were given along with oral pyrimethamine, $25 \mathrm{mg}$ twice a day, and folinic acid. Because of deteriorating consciousness, assisted ventilation and subsequently tracheostomy were required. As the patient had not responded to previous treatment, on day $\mathbf{4 4}$ spiramycin $1 \mathrm{~g}$, twice a day, and sulphatriad, $500 \mathrm{mg}$ four times a day, were given instead of trimethoprim and sulphadiazine. He made a steady recovery. Sulphatriad treatment was stopped on day 109 and he was discharged.Antitoxoplasma treatment was discontinued at 11 months. A blood sample taken two years after transplantation, however, showed a rise in the $T$ gondii latex agglutination, dye test, and haemagglutination antibody titres, although he was asymptomatic.

A 44 year old man (case 5) had received a heart and lung transplant. As he was mismatched for $T$ gondii he received prophylaxis with pyrimethamine and folinic acid. After five weeks of pyrimethamine he became neutropenic. Treatment with pyrimethamine was therefore stopped. Subsequently, the patient developed CMV infection but symptoms were only mild. He remained well until 14 months after transplantation when a transbronchial biopsy specimen showed evidence of rejection. Immunosuppressive treatment was therefore increased. He subsequently developed a respiratory tract infection with a productive cough and the $T$ gondii latex agglutination test antibody titre rose from $<16$ to 1024 . The patient received a brief course of pyrimethamine ( $25 \mathrm{mg}$ a day) and made an uneventful recovery. $T$ gondii cysts were not found in myocardial biopsy specimens taken on days 17 and 39 after transplantation and transbronchial biopsy specimens taken on days 23 and 54 after transplantation.

A 47 year old man (case 6) had received a cardiac transplant. As he was mismatched for $T$ gondii, he was given prophylaxis with pyrimethamine and folinic acid. One hundred and fifteen days after transplantation his $T$ gondii latex agglutination test antibody titre rose from $<16$ to 1024 . He did not have any symptoms. $T$ gondii cysts were not found in regular myocardial biopsy specimens taken after transplantation.

A 49 year old man (case 7) had been given a cardiac transplant. Seventy five days after transplantation the latex agglutination test titre had risen from 32 to 256 , indicating recrudescence of $T$ gondii. The patient was asymptomatic without fever. $T$ gondii cysts were not seen in routine myocardial biopsy specimens taken after transplantation.

A 50 year old man (case 8) had received a heart transplant. Twelve days after transplantation he had enlarged cervical nodes, arthralgia of ankles and wrists, as well as an erythematous rash. By day 30 , a low grade fever had developed. He subsequently developed general malaise and was treated from day 63 with spiramycin ( $1 \mathrm{~g}$ twice a day), sulphatriad (500 $\mathrm{mg}$ four times a day), and pyrimethamine ( $25 \mathrm{mg}$ twice a day). After six weeks his temperature settled and his general condition gradually improved. Treatment with sulphatriad, pyrimethamine, and spiramycin was stopped on days 77,100 , and 115 , respectively. $T$ gondii cysts were not seen in numerous cardiac biopsy specimens taken after transplantation.

A 23 year old woman (case 9) had received a heart and lung transplant. At nine months a mild fever and 
left lower lobe pneumonia developed, together with a rise in $T$ gondii latex agglutination antibody test titre to 16000 . Treatment with intravenous sulphadimidine, $2 \mathrm{~g}$ three times a day, was started. Although the fever settled spontaneously, shortness of breath persisted. Two weeks later treatment was changed to oral pyrimethamine, $25 \mathrm{mg}$ twice a day, and folinic acid, which was given for one month. She developed Pneumocystis carinii infection at 12 months and died with obliterative bronchiolitis 14 months after the operation. $T$ gondii cysts were not seen in 11 myocardial biopsy specimens taken at regular intervals from day 7 to day 184, nor in transbronchial biopsy specimens taken on days 142 to 334 .

\section{Discussion}

In this series we disregarded those patients whose serial serum samples showed rising latex agglutination test antibody titres as a result of $T$ gondii antibody passively acquired from blood transfusion, as well as those who had a non-specific rise in latex agglutination test antibody titres concurrently with active CMV infection. These have been reported previously. ${ }^{19}$

We have shown that four of seven patients $(57 \%)$ mismatched for $T$ gondii who did not receive prophylaxis with pyrimethamine developed primary donor acquired $T$ gondii infection. ${ }^{8}$ In the Stanford series, Luft et al found that three of four (75\%) patients mismatched for $T$ gondii developed lifethreatening primary $T$ gondii infection. ${ }^{7}$ There is therefore general agreement that when patients are mismatched for $T$ gondii, there is a high risk of their developing serious or fatal toxoplasmosis. We have further shown that prophylactic pyrimethamine $(25 \mathrm{mg} /$ day for six weeks) prevents or mitigates the effects of $T$ gondii infection in mismatched patients. Two such patients (cases 5 and 6) in this study developed primary $T$ gondii infection despite prophylaxis with pyrimethamine. Case 5, however, received only a five week course of pyrimethamine because of neutropenia. He developed symptomatic $T$ gondii infection 14 months after transplantation, shortly after his immunosuppressive regimen was intensified because of a rejection episode. The enhancement of the immunosuppressive regimen may have been responsible for the activation of the latent $T$ gondii in the donor heart, and it may be necessary to give a further prophylactic course of pyrimethamine when rejection episodes necessitate increased immunosuppressive treatment. Case 6 should have received a full course of pyrimethamine, but due to poor compliance, he may not have taken the full course. Primary $T$ gondii infection developed around four months after transplantation. His infection was probably asymptomatic because he had not received enhanced immunosuppressive treatment, and had not experienced episodes of rejection. The primary toxoplasmosis in these two patients had two rather atypical features: infection was noted much later than in the other four patients who did not receive pyrimethamine; and symptoms were mild or absent.

In the first four patients who developed primary $T$ gondii infection symptoms were noted within five weeks of transplantation (on days 17, 20, 22 and 32). The first indication of $T$ gondii infection in all of them was fever. Three developed respiratory tract symptoms and one had grand mal fits with loss of consciousness. In the series reported by Luft et al two patients developed symptoms four to six weeks after transplantation and died. ${ }^{7}$ One was found to have chorioretinitis six months after transplantation. Four months later he became mentally confused and three brain abscesses were found on a computed tomographic scan. Interestingly, the two patients in our series who died from disseminated $T$ gondii infection both received an additional course of steroids for the treatment of organ rejection, while the two who survived did not. This increased immunosuppression probably enhanced the severity of disease.

Of the 75 patients in this series who were $T$ gondii antibody positive before transplantation, only three $(4 \%)$ had genuine rises in latex agglutination, dye test, and haemagglutination test antibodies after transplantation, indicating recrudescence of $T$ gondii. One (case 7) received azathioprine and prednisolone; case 8 was given cyclosporin $\mathbf{A}$ and low dose steroids; and case 9 had triple treatment as the immunosuppressive regimen. This incidence of $T$ gondii recrudescence contrasts with that reported by Luft et al, ${ }^{7}$ who reported that $10(53 \%)$ of 19 heart transplant recipients in the Stanford series who were antibody positive before transplantation had serological evidence of $T$ gondii recrudescence after transplantation. Eight $(80 \%)$ of their 10 patients who received azathioprine had $a \geqslant$ four-fold rise in dye test antibody titres compared with only two $(25 \%)$ of the eight patients receiving cyclosporin $A$. None of the nine patients in this series, who were $T$ gondii antibody positive before transplantation and had been given azathioprine and one $(5.9 \%)$ of the 17 given cyclosporin A, had a subsequent rise in $T$ gondii antibody titre. There does seem to be a discrepancy between the two series which is difficult to explain. It may be that the differences can be attributed to the amounts of immunosuppressive treatment given in the two groups of patients.

None of the patients in the Stanford series developed clinical illness attributable to $T$ gondii recrudescence compared with two of the three patients in our series. Interestingly, case 7 did not receive enhanced immunosuppressive treatment as a result of 
graft rejection, but cases 8 and 9 did at the time their $T$ gondii antibodies increased in titre.

In our series all of the patients with primary $T$ gondii infection who produced an antibody response seroconverted in the latex agglutination, dye test, and haemagglutination tests, produced $T$ gondii-specific IgM, and had demonstrable $T$ gondii visible in biopsy or necropsy specimens. All of the five patients with $T$ gondii recrudescence showed an antibody response in the latex agglutination, dye test, and haemagglutination tests, but only two (cases 4 and 9) produced a $T$ gondii-specific IgM antibody response. None of these patients had demonstrable $T$ gondii in biopsy specimens taken at any time after transplantation. Luft et al found $T$ gondii-specific IgM in four $(\mathbf{4 0 \% )}$ ) of their patients with $T$ gondii recrudescence, ${ }^{7}$ which is similar to our findings.

In conclusion, we have found in the Papworth heart transplant series that $T$ gondii infection is life-threatening only when acquired from the donor organ and that prophylactic pyrimethamine prevents or mitigates the effect of this infection.

\section{References}

1 Fleck DG. Toxoplasmosis. Public Health 1969;83:131-5.

2 Ruskin J, Remington JS. Toxoplasmosis in the compromised host. Ann Int Med 1976;84:193-9.

3 Vietzke WM, Gelderman AH, Grimley PM. Toxoplasmosis complicating malignancy. Cancer 1968;21:816-27.

4 Hauser WE, Luft BJ, Conley FK, Remington JS. Central nervoussystem toxoplasmosis in homosexual and heterosexual adults. $N$ Engl J Med 1982;307:498-9.

5 Reynolds ES, Walls KW, Pfeiffer RI. Generalised toxoplasmosis following renal transplantation. Arch Intern Med 1966;118: 401-5.

6 Higgenbottam T, Stewart S, Wallwork J. Transbronchial lung biopsy to diagnose lung rejection and infection of heart-lung transplants. Trans Proc 1988;XX(suppl I):767-9.
7 Luft BJ, Naot Y, Araujo FG, Stinson EB, Remington JS. Primary and reactivated Toxoplasma infection in patients with cardiac transplants. Clinical spectrum and problems in diagnosis in a defined population. Ann Int Med 1983;99:27-31.

8 Hakim M, Esmore D, Wreghitt TG, Wallwork J, English TAH. Toxoplasmosis in cardiac transplantation. Br Med J 1986;292: 1108.

9 Hirsch R, Burke BA, Kersey JH. Toxoplasmosis in bone marrow transplant recipients. J Paediatr 1984;105:426-8.

10 Walls KW, Taraska JJ, Goldman M. Isolation of Toxoplasma gondii from cysts in human brain. J Parasitol 1963;49:930-1.

11 Remington JS, Cavanaugh EN. Isolation of encysted forms of Toxoplasma gondii from human skeletal muscle and brain. $N$ Engl J Med 1965;273:1308-10.

12 English TAH, McGregor C, Wallwork J, Cory-Pearce R. Aspects of immunosuppression for cardiac transplantation. Heart Transplantation 1982;1:280-4.

13 Wallwork J, Cory-Pearce R, English TAH. Cyclosporine for cardiac transplantation: UK trial. Trans Proc 1983;XV: 2559-66.

14 Hunter D, Chadwick P, Balfour AH, Bridges JB. Examination of ovine foetal fluid for antibodies to Toxoplasma gondii by the dye test and an indirect immunofluorescence test for specific IgM. Br Vet J 1982;138:29-33.

15 Hunter D, Chadwick P, Balfour AH, Bridges JB. An assessment of a commercially available haemagglutination test for detecting toxoplasma antibodies in ovine sera. Br Vet J 1980;136:339-42.

16 Payne RA, Joynson DHM, Balfour AH, et al. Public Health Laboratory Service enzyme-linked immunosorbent assay for detecting Toxoplasma-specific IgM antibody. J Clin Pathol 1987;40:276-81.

17 Pomerance A, Stovin PGI. Heart transplant pathology: The British Experience. J Clin Pathol 1985;38:146-59.

18 McGregor CGA, Fleck DG, Nagington J, Stovin PGI, CoryPearce R, English TAH. Disseminated toxoplasmosis in cardiac transplantation. J Clin Pathol 1984;37:74-7.

19 Wreghitt TG, Gray JJ, Balfour AH. Problems with the serological diagnosis of Toxoplasma gondii infections in heart transplant recipients. J Clin Pathol 1986;39:1135-9.

Requests for reprints to: Dr T G Wreghitt, Public Health Laboratory, Level 6, Addenbrooke's Hospital, Hills Road, Cambridge CB2 2QW, England. 